\title{
Survei Infestasi Lalat Stomoxys spp. pada Sapi Bali di Wilayah Kabupaten Badung
}

\section{(SURVEY OF STOMOXYS SPP. FLIES INFESTATION ON BALI CATTLE IN BADUNG REGENCY)}

\author{
Dhea Septiany Peda Lalupada ${ }^{1 *}$, I Made Dwinata ${ }^{2}$, Ida Bagus Made Oka ${ }^{2}$ \\ ${ }^{1}$ Mahasiswa Sarjana Kedokteran Hewan, Fakultas Kedokteran Hewan, Universitas Udayana, \\ Jl. PB. Sudirman Denpasar, Bali; ${ }^{2}$ Laboratorium Parasitologi Veteriner, \\ Fakultas Kedokteran Hewan, Universitas Udayana, Jl. PB. Sudirman Denpasar, Bali. \\ *Email: dheealalupada@gmail.com
}

\begin{abstract}
Abstrak
Sapi bali merupakan ternak yang banyak dipelihara oleh masyarakat di Kabupaten Badung. Lalat Stomoxys spp. merupakan salah satu ektoparasit penghisap darah pada sapi dan juga berperan sebagai vektor dari beberapa penyakit seperti rickettsia (anaplasma marginale), surra (trypanosoma evansi), besnoitiosis (besnoitia besnoiti). Penelitian ini bertujuan untuk mengetahui prevalensi lalat Stomoxys spp. pada sapi bali di Kabupaten Badung, serta hubungan cara pemeliharaan, kondisi wilayah, jenis kelamin dan umur terhadap infestasi lalat Stomoxys spp. Sampel penelitian ditentukan secara purposive dengan jumlah sampel 300 ekor sapi bali. Penelitian ini merupakan penelitian observasional dengan rancangan Cross-sectional. Hasil penelitian menunjukkan bahwa prevalensi infestasi lalat Stomoxys spp. di Kabupaten Badung adalah 50,3\%. Prevalensi infestasi lalat Stomoxys spp. pada ternak yang dikandangkan (59\%) lebih tinggi terinfestasi lalat Stmoxys spp. dibandingkan dengan ternak yang diikat (33\%), sedangkan pada wilayah lahan basah (59\%) lebih tinggi prevalensinya dibandingkan wilayah lahan kering (33\%). Prevalensi ternak muda $(51,4 \%)$ paling tinggi terinfestasi lalat Stomoxys spp. dibandingkan dengan ternak dewasa $(50 \%)$ dan ternak tua (45.5\%), prevalensi infestasi lalat Stomoxys spp. pada ternak betina $(58,1 \%)$ lebih tinggi dibandingkan ternak jantan $(35,3 \%)$. Faktor kondisi wilayah, cara pemeliharaan dan jenis kelamin sangat berpengaruh $(\mathrm{P}<0,05)$ terhadap infestasi lalat Stomoxys spp. pada sapi bali di Kabupaten Badung, namun umur tidak berpengaruh ( $\mathrm{P}>0,05)$.
\end{abstract}

Kata kunci: Prevalensi; sapi bali; lalat Stomoxys spp.

\begin{abstract}
Bali cattle are a lot of livestock raised by people in Badung Regency. Stomoxys spp. Flies is one of the blood-sucking ectoparasites and also acts as a vector of several diseases such as Rickettsia (anaplasma marginale), surra (trypanosoma evansi), besnoitiosis (besnoitia besnoiti). Factors that can affect the presence of Stomoxys spp. in cattle including maintenance, regional conditions and gender. This study aims to determine the prevalence of Stomoxys spp. in Bali cattle in Badung Regency, as well as the relationship between how to maintain, the condition of the region, gender and age of Stomoxys spp. The research sample was determined purposively with a sample of 300 Bali cattle. This study was an observational study with a cross-sectional design. The results showed that the prevalence of Stomoxys spp. in Badung Regency is 50.3\%. The prevalence of Stomoxys spp. on stranded livestock (59\%) higher infestation by Stmoxys spp. compared to tied cattle (33\%), while in wetland areas (59\%) the prevalence is higher than dryland areas (33\%). The highest prevalence of young livestock $(51.4 \%)$ was infested by Stomoxys spp. compared to adult cattle (50\%) and old livestock (45.5\%), the prevalence of Stomoxys spp. in female cattle (58.1\%) higher than male cattle (35.3\%). Factors in area conditions, maintenance methods and sex were very influential ( $\mathrm{P}<0.05)$ on Stomoxys spp. in Bali cattle in Badung Regency, but age has no effect $(\mathrm{P}>0.05)$.
\end{abstract}

Keywords: Prevalence; Stomoxys spp.; flies; bali cattle. 


\section{PENDAHULUAN}

Kabupaten Badung merupakan salah satu kabupaten yang terletak di provinsi Bali, Indonesia. Sapi Bali merupakan ternak yang paling banyak dipelihara oleh masyarakat di Kabupaten Badung. Sapi bali termasuk jenis sapi potong yang merupakan satu diantara komoditas peternakan yang dapat mendukung pemenuhan kebutuhan akan bahan pangan bergizi tinggi (Direktorat Jenderal Peternakan, 2011; Besung et al., 2019). Tingginya permintaan akan daging dapat mengakibatkan peningkatan jumlah peternakan dan juga dapat meningkatkan taraf hidup serta perekonomian masyarakat di Kabupaten Badung (BPS, 2009; Sarassati dan Agustina, 2015; Agustina et al., 2017; Laksmi et al., 2019). Permasalahan usaha ternak sapi saat ini yang dirasakan salah satunya adalah penyakit ektoparasit. Satu diantara ektoparasit yang berperan sebagai vektor penyakit yang sering menginfestasi sapi adalah lalat (Putra, 2012).

Stomoxys spp. atau lalat kandang adalah lalat penghisap darah yang tersebar luas di dunia dan juga dilaporkan berperanan penting dalam penyebaran penyakit protozoa dan bakteri pada ternak besar (Safitri et al., 2017). Kerugian pada sapi potong berupa kehilangan darah, tertular suatu penyakit, dan ketidaknyamanan sehingga sapi akan mengalami penurunan bobot badan dan produksi. Lalat Stomoxys spp. pengganggu ini memiliki probosis tipe penusuk, penghisap darah dan juga mengakibatkan kerugian ekonomi yang besar bagi produksi hewan karena rasa sakit dan energi yang terbuang pada hewan dalam upaya menghindari gangguan yang dihasilkan dari gigitan lalat (Castro et al., 2007). Adanya lalat Stomoxys spp. pada kandang dan sekitar kandang sapi perlu diperhatikan karena keberadaan vektor tersebut dapat menularkan beberapa penyakit seperti rickettsia yang disebabkan oleh Anaplasma marginale (Garfias et al., 2007), surra disebabkan oleh Trypanosoma evansi (Sukanto et al., 2000), besnoitiosis yang disebabkan oleh Besnoitia besnoiti (Lienard et al., 2011).

Kejadian infeksi parasit berpengaruh terhadap cara pemeliharaan hewan ternak (Tolistiawaty et al., 2016). Penyakit yang disebabkan parasit umumnya menyerang ternak yang dipelihara dengan tata laksana yang kurang baik misalnya hewan tidak dikandangkan, tidak pernah dimandikan, digembalakan didaerah yang tergenang air (Widnyana, 2013; Tolistiawaty et al., 2016). Kondisi lingkungan seperti suhu, curah hujan, dan kelembaban menjadi faktor utama yang dapat mempengaruhi aktivitas dari lalat Stomoxys spp. sehingga berpengaruh terhadap peningkatan dan penurunan populasi lalat Stomoxys spp. (Barry dan Campbell, 1985). Penelitian ini bertujuan untuk mengetahui prevalensi dan hubungan antara cara pemeliharaan, jenis kelamin, kondisi wilayah dan umur dengan prevalensi infestasi lalat Stomoxys spp. pada sapi bali di Kabupaten Badung.

\section{MATERI DAN METODE}

\section{Objek Penelitian}

Sampel penelitian ini adalah sapi bali yang diambil dari wilayah lahan basah (Kecamatan Petang, Abiansemal, Mengwi) dan kering (Kecamatan Kuta, Kuta Utara, Kuta Selatan), ditentukan secara purposive di Kabupaten Badung. Jumlah sampel yang digunakan dalam penelitian ini adalah 300 sampel (Thrusfield, 2007).

\section{Cara Pengambilan Sampel}

Tubuh sapi bali diamati secara keseluruhan, apakah terlihat lalat. Jika ditemukan adanya lalat, ditangkap menggunakan Sweeping net dengan cara mengayunkan Sweeping net ke arah lalat secara berulang sampai mendapatkan lalat, kemudian pada bagian atas Sweeping net ditutup menggunakan tangan yang satunya agar lalat tidak dapat terbang keluar, lalat dimasukkan ke dalam pot sampel. Setiap sampel direndam dengan larutan alkohol $70 \%$ sebagai pengawet sampai merendam 
seluruh lalat (Soulsby, 1982), kemudian diberi label yang memuat keterangan untuk dapat dijadikan sebagai penanda setiap sampel. Sampel yang telah terkumpul dibuat preparat permanen dan diperiksa di Laboratorium Parasitologi Fakultas Kedokteran Hewan Universitas Udayana.

\section{Pemeriksaan Sampel}

Identifikasi lalat secara mikroskopis, dilakukan dengan pemeriksaan preparat awetan permanen (Soulsby, 1982). Cara pembuatan preparat awetan permanen lalat sesuai dengan Soulsby, 1982 dengan modifikasi adalah sebagai berikut: pertama yang dilakukan adalah lalat dari pot sampel dituangkan ke cawan petri, selanjutnya lalat dipindahkan ke object glass, untuk memisahkan kepala dan sayap lalat menggunakan scapel ukuran 11 agar sampel tidak rusak (sambil dilihat dibawah mikroskop dan diatur menggunakan spuit 1 $\mathrm{ml}$ ) jepit dengan object glass yang lain dan diikat menggunakan karet kedua ujungnya. Object glass tersebut dimasukan ke dalam alcohol $80 \%$ minimal selama 1 jam yang bertujuan untuk proses pengeluaran cairan (dehidrasi), kemudian dilanjutkan perendaman dengan methanol minimal selama 24 jam. Sampel yang telah direndam diangkat dan dibuka, kemudian bagian yang basah di lap menggunakan tisu, selanjutnya ditetesi minyak kayu putih secukupnya yang bertujuan untuk penjernihan dan ditutup dengan cover glass dibiarkan selama minimal 30 menit. Setelah 30 menit cover glass dibuka perlahan menggunakan silet dan dikeringkan menggunakn tisu. Tahap selanjutnya yaitu perlekatan, lalat ditetesi entelan dan terakhir tutup dengan gelas penutup. Pemeriksaan dengan mikroskop untuk tujuan identifikasi adanya lalat pada sapi bali berdasarkan ciri morfologinya (Soulsby,1982).

\section{Analisis Data}

Data hasil pemeriksaan dianalisis secara deskriptif dan untuk mengetahui hubungan antara faktor yang berpengaruh terhadap prevalensi infestasi lalat diuji dengan uji Chi-square menggunakan program SPSS Versi 22.0. (Sampurna dan Nindhia, 2008).

\section{HASIL DAN PEMBAHASAN}

\section{Hasil}

Hasil pemeriksaan terhadap 300 sampel sapi bali di Kabupaten Badung menunjukkan bahwa 200 sampel dipelihara pada wilayah lahan basah sedangkan 100 sampel dipelihara pada wilayah lahan kering. Hasil yang didapatkan sebanyak 151 sampel positif $(50,3 \%)$ terinfestasi lalat Stomoxys spp.

Berdasarkan hasil penelitian, dari total 200 sampel ternak yang dikandangkan ditemukannya 118 sampel positif infestasi lalat Stomoxys spp. dengan prevalensi 59\%. Sedangkan, pada ternak yang diikat terdapat 33 sampel positif dari total 100 sampel dengan prevalensi 33\%. Didapatkan hasil bahwa cara pemeliharan pada ternak yang dikandangkan lebih tinggi terinfestasi lalat Stmoxys spp. dibandingkan dengan ternak yang diikat. Hasil analisis Chisquare menunjukan bahwa cara pemeliharaan berpengaruh $(\mathrm{P}<0,05)$ terhadap infestasi lalat Stomoxys spp. (Tabel 1).

Tabel 1. Prevalensi Infestasi Stomoxys spp. berdasarkan cara pemeliharaan.

\begin{tabular}{lcccc}
\hline Cara Pemeliharaan & Sampel & Positif & Prevalensi (\%) & Sig. \\
\hline Dikandangkan & 200 & 118 & 59 & 0,00 \\
Diikat & 100 & 33 & 33 & \\
Total & 300 & 151 & & \\
\hline
\end{tabular}

Dari total 200 sampel terdapat 118 sampel positif terinfestasi lalat Stomoxys spp. dengan prevalensi sebesar 59\% ditemukan di daerah lahan basah dan ditemukan lebih sedikit di daerah lahan kering yaitu sejumlah 33 sampel $33 \%$ positif teinfestasi lalat stomoxys. Setelah dilakukan analisis dengan Chi-square 
menunjukkan bahwa terdapat hubungan yang berpengaruh $(\mathrm{P}<0,05)$ antara wilayah lahan basah dan lahan kering dengan prevalensi infestasi lalat Stomoxys spp. pada sapi bali di Wilayah Kabupaten Badung (Tabel 2).

Infestasi lalat Stomoxys spp. pada ternak muda dengan rentang umur $<2$ tahun yaitu sejumlah 54 sampel yang positif dari 105 sampel dengan prevalensi 51,4\%. Ternak dewasa dengan rentang umur umur $>2-8$ tahun terdapat 92 sampel positif terinfestasi lalat Stomoxys spp. dari 184 sampel dengan prevalensi sebesar $50 \%$. Sedangkan, pada ternak tua dengan rentang umur $>8$ tahun ditemukan 5 sampel positif dari 11 sampel dengan prevalensi sebesar 45.5\%. Prevalensi ternak muda paling tinggi terinfestasi lalat Stomoxys spp. dibandingkan dewasa dan ternak tua. Hasil analisis Chi-square menunjukan bahwa umur tidak berpengaruh $(\mathrm{P}>0,05)$ terhadap infestasi lalat Stomoxys spp. (Tabel 3).

Infestasi lalat Stomoxys spp. pada ternak jantan ditemukan 36 sampel positif dari 102 sampel dengan prevalensi sebesar $35,3 \%$. Sedangkan pada ternak betina ditemukan 115 sampel positif dari 198 sampel dengan prevalensi sebesar 58,1\%. Prevalensi infestasi lalat Stomoxys spp. pada ternak betina lebih tinggi dibandingkan jantan. Hasil analisis Chisquare menunjukkan bahwa jenis kelamin berpengaruh $(\mathrm{P}<0,05)$ terhadap infestasi lalat Stomoxys spp. pada sapi bali di wilayah Kabupaten Badung (Tabel 4).

Tabel 2. Prevalensi Infestasi Stomoxys spp. berdasarkan wilayah.

\begin{tabular}{lcccc}
\hline Tipe lahan & Sampel & Positif & Prevalensi (\%) & Sig. \\
\hline Basah & 200 & 118 & 59 & 0,00 \\
kering & 100 & 33 & 33 & \\
Total & 300 & 151 & & \\
\hline
\end{tabular}

Tabel 3. Prevalensi Infestasi Stomoxys spp. berdasarkan umur.

\begin{tabular}{lcccc}
\hline Umur & Sampel & Positif & Prevalensi (\%) & Sig. \\
\hline Muda & 105 & 54 & 51,4 & 0,922 \\
Dewasa & 184 & 92 & 50 & \\
Tua & 11 & 5 & 45,5 & \\
Total & 300 & 151 & & \\
\hline
\end{tabular}

Tabel 4. Prevalensi Infestasi Stomoxys spp. berdasarkan jenis kelamin.

\begin{tabular}{lcccc}
\hline Jenis Kelamin & Sampel & Positif & Prevalensi (\%) & Sig. \\
\hline Jantan & 102 & 36 & 35,3 & 0,00 \\
Betina & 198 & 115 & 58,1 & \\
Total & 300 & 151 & & \\
\hline
\end{tabular}

\section{Pembahasan}

Pada penelitian ini, didapatkan prevalensi infestasi lalat Stomoxys spp. pada sapi bali yang dipelihara di wilayah Kabupaten Badung adalah sebesar 50,3\%. Sedangkan, penelitian mengenai keberadaan lalat Stomoxys spp. pernah dilakukan oleh Ikasari (2013) bahwa ditemukan lalat Stomoxys spp. sebagai lalat pengganggu pada 18 peternakan sapi potong di daerah Cirebon bahwa terdapat empat jenis spesies dari lalat kandang Stomoxys calcitrans (89.68\%), S. sitiens
(5.01\%), S. indicus (4.2\%) dan $S$. bengalensis (1.09\%). Lalat Stomoxys spp. tidak hanya ditemukan pada sapi, tetapi ditemukan juga menginfestasi anoa seperti penelitian yang dilakukan oleh Rifal di (2017) pada Anoa Breeding Center Balai Penelitian dan Pengembangan Lingkungan Hidup dan Kehutanan (Bp2lhk).

Berdasarkan hasil penelitian, populasi lalat Stomoxys spp. pada sapi betina lebih tinggi dibandingkan sapi jantan. Penelitian ini berbeda dengan penelitian yang dilakukan oleh Ahmad (2008) yang 
mengambil sampel pada sapi perah, yang menyatakan bahwa kondisi tubuh ternak mempengaruhi banyak tidaknya jumlah parasit pada ternak, sehingga jika parasit ditemukan dalam jumlah yang banyak pada satu jenis kelamin, kemungkinan dipengaruhi oleh faktor stres pada ternak tersebut. Tingginya kadar prolaktin dan hormon progesteron membuat ternak betina lebih rentan terhadap infestasi parasit. Sapi betina sering mengalami stres bila dibandingkan dengan sapi jantan. Proses bunting, melahirkan dan laktasi umumnya menyebabkan stres pada sapi betina. (Kaur et al., 2015; Dehuri et al, 2017). Selain itu, kebiasaan lalat yaitu berpindah-pindah dari satu ternak ke ternak yang lain sehingga memungkinkan bila dalam suatu populasi didapatkan jenis kelamin betina lebih banyak terinfestasi dibandingkan jantan begitupun sebaliknya.

Pada penelitian ini, populasi lalat Stomoxys spp. yang menginfestasi sapi bali lebih tinggi prevalensinya pada kondisi wilayah di daerah lahan basah dibandingkan dengan daerah lahan kering. Kondisi kandang di wilayah lahan basah yang ditemukan dilapangan, peternak masih kurang memperhatikan kebersihan kandang. Feses dan urine ternak dibiarkan menumpuk pada alas kandang dan sekitar kandang, sehingga menyebabkan kondisi kandang yang kotor dan bau. Oleh karena itu, Sesuai dengan nama lain Stomoxys spp. yang merupakan lalat kandang, Stomoxys spp. lebih banyak ditemukan pada sapi yang dikandangkan. Sedangkan untuk wilayah lahan kering dapat menyebabkan feses sapi bali lebih cepat mengering sehingga jarang dihinggapi lalat (Depkes RI, 1992).

Menurut data dari Badan Meteorologi Klimatologi dan Geofisika kelas III Denpasar, (BMKG, 2018) rata-rata suhu pada Kecamatan Kuta Selatan dan Kuta yaitu $27,5^{\circ} \mathrm{C}-28,3^{\circ} \mathrm{C}$, dengan kelembaban udara $78 \%$ - 80\%, dan curah hujan 11,1 15,6 mm. Sedangkan pada lahan basah yaitu pada Kecamatan Mengwi, Abiansemal, dan Petang dengan rata-rata suhu $21^{0} \mathrm{C}-26^{0} \mathrm{C}$, dengan kelembaban udara $89 \%$ - 93\% dan curah hujan 474,5 $599,0 \mathrm{~mm}$. Kondisi iklim seperti suhu, kelembaban, dan curah hujan pada wilayah lahan basah mendukung keberadaan lalat Stomoxys spp. Hasil penelitian ini didukung oleh penelitian terdahulu yaitu penelitian yang dilakukan oleh Vazquez et al. (2004) yang menyatakan bahwa kelembaban memiliki korelasi tinggi terhadap peningkatan populasi lalat Stomoxys spp.

Berdasarkan hasil penelitian antara umur sapi muda, dewasa, dan tua tidak berpengaruh terhadap prevalensi infestasi lalat Stomoxys spp. pada sapi bali di wilayah Kabupaten Badung. Hal ini disebabkan karena pada umumnya cara pemeliharaan pada sapi bali yang semi intensif baik pada sapi muda, dewasa, dan tua tidak dipisahkan dan juga dikarenakan sifat lalat yang terbang dan dapat berpindah dari satu sapi ke sapi lainnya (Kertawirawan, 2013).

\section{SIMPULAN DAN SARAN}

\section{Simpulan}

Berdasarkan hasil dan pembahasan, dapat disimpulkan bahwa Prevalensi infestasi lalat Stomoxys spp. pada sapi bali di wilayah Kabupaten Badung sebesar 50,3 $\%$ kondisi wilayah, cara pemeliharaan dan jenis kelamin merupakan faktor yang berhubungan dengan infestasi lalat Stomoxys spp., sedangkan umur tidak berpengaruh.

\section{Saran}

Prlu dilakukan kontrol terhadap prevalensi infestasi lalat Stomoxys spp. pada sapi bali untuk mengoptimalkan produksi maupun kesehatan ternak.

\section{UCAPAN TERIMAKASIH}

Penulis mengucapkan terimakasih kepada Laboratorium Parasitologi Veteriner Fakultas Kedokteran Hewan Universitas Udayana yang telah memfasilitasi penelitian ini. 


\section{DAFTAR PUSTAKA}

Agustina KK, Cahya IMRD, Widyantara GM, Swacita IBN, Dharmayudha AAGO, Rudyanto MD. 2017. Nilai gizi dan kualitas fisik daging sapi bali berdasarkan jenis kelamin dan umur. Buletin Vet. Udayana. 9(2): 156-163.

Ahmad RZ. 2008. Beberapa penyakit parasitik dan mikotik pada sapi perah yang harus diwaspadai. Balai Besar Penelitian Veteriner. Bogor.

Badan Pusat Statistik. 2010. Statistik Peternakan. Tersedia di: www.bps.co.id Diakses pada tanggal 5 Mei 2019.

Barry LL, Campbell JB. 1985. Time and weather effect on daily feeding pattern of stable flies (Diptera: Muscidae). Envi. Ent. (14): 336-342.

Besung INK, Watiniasih NL, Mahardika GNK, Agustina KK, Suwiti NK. 2019. Mineral levels of Bali cattle (Bos javanicus) from different types of land in Bali, Nusa Penida, and Sumbawa Islands (Indonesia). Biodiversitas. 20(10): 2931-2936.

BMKG, Badan Meteorologi Klimatologi dan Geofisika. 2018. Data Suhu, Kelembaban, dan Curah Hujan. Denpasar.

Castro BGD, Milliane MS, Souza D, Avelino JB. 2007. Aerobic bacterial microbiota in Stomoxys calcitrans: preliminary studies in Brazil. J. Vet. Parasitol. 16(4): 193-197.

Depkes RI. 1992. Petunjuk Teknis Tentang Pemberantasan Lalat. Jakarta: Ditjen PPM \& PLP.

Direktorat Jenderal Peternakan dan Kesehatan Hewan. 2011. Statistik peternakan tahun 2011. Ditjen Peternakan dan Kesehatan Hewan. Kementerian Pertanian. Jakarta.

Garfias CRB, Flores APM, Hernandes IG. 2007. Effect of feeding Stomoxys calcitrans (Diptera: Muscidae) with blood from Bos taurus immunized with concealed antigens from the stable fly on the oviposition. Vet. Méxic. 38(2): 177-183.
Ikasari AP. 2013. Keragaman jenis lalat pengganggu dan potensi permasalahannya pada ternak sapi potong Di Daerah Cirebon. Tesis. Fakultas Kedokteran Hewan. Instutut Pertanian Bogor. Bogor.

Kertawirawan IPA. 2013. Pengaruh tingkat sanitasi dan sistem manajemen perkandangan dalam menekan angka kasus koksidiosis pada pedet sapi bali. Laporan Penelitian. Balai pengkajian Teknologi Prtanian Bali. Denpasar

Laksmi DNDI, Trilaksana IGNB, Darmanta RJ, Darwan M, Bebas IW, Agustina KK. 2019. Correlation between body condition score and hormone level of Bali cattle with postpartum anestrus. Indian J. Anim. Res. 2019(53): 1599-1603.

Liénard E, Salema A, Grisez C, Prévot F, Bergeauda JP, Franc M, Gottstein B, Alzieu JP, Lagalisse Y, Jacquiet P, 2011. A longitudinal study of Besnoitia besnoiti infections and seasonal abundance of Stomoxys calcitrans in a dairy cattle farm of southwest France. Vet. Parasitol. 117: 20-27.

Muenworn V, Gerard D, Krajan T, Siripun T, Somchai T, Atchariya P, Pongthep A, Suprada S, Theeraphap C. 2010. G eographic distribution of Stomoxyine flies (Diptera: Muscidae) and diurnal activity of Stomoxys calcitrans in Thailand. J. Med. Entomol. 47(5): 791797.

Putra J. 2012. Identifikasi lalat sumba (Hippobosca Spp.) pada sapi perah di kawasan usaha peternakan sapi perah Cibungbulang Kabupaten Bogor. Skripsi. Fakultas Kedoktran Hewan. Institut Pertanian Bogor. Bogor

Putra SK, Ardika NK, Artiningsih K, Saka, Kayana IGN. 2006. Pendekatan terpadu dalam melestarikan dan mengembangkan sapi bali sebagai bibit dan daging yang berkualitas. Tim Peneliti Sapi Bali Nusa Penida, Fakultas Peternakan, Universitas Udayana. 
Rifaldi AA. 2017. Identifikasi keragaman jenis ektoparasit pada anoa (Babalus Spp) di anoa breeding center Balai Penelitian Dan Pengembangan Lingkungan Hidup Dan Kehutanan (BP2LHK) Manado. Fakultas Kedokteran Hewam. Universitas Hasanuddin. Makasar.

Safitri V, Hastutik P, Arimbi. 2017. Identifikasi bakteri pada eksoskeleton lalat di beberapa pasar di Surabaya. $J$. Parasitol. Sci. 1(1): 1-6.

Sampurna IP, Nindhia TS. 2008. Analisis data dengan SPSS dalam rancangan percobaan. Udayana University Press. Denpasar.

Sarassati T, Agustina KK. 2015. Kualitas daging sapi wagyu dan daging sapi bali yang disimpan pada suhu-19 ${ }^{\circ} \mathrm{C}$. Indonesia Vet. Med. 4(3): 178-185.

Sukanto IP, Politedy FL, Solihat, Dachlan M, Wardhana, Satria E. 2000. Peran diptera hematofagus sebagai vektor Trypanosoma evansi. Proc. Seminar Nasional Peternakan dan Veteriner. Pp. 481-487.

Soulsby EJL. 1982. Helminths, Arthropods and protozoa of domesticated animals. $7^{\text {th }}$ Ed. William and Wilkin, Bailliere Tindall, London.
Thomas G, Jespersen JB. 1994. Non-biting Muscidae and control methodes. Rev. Sci. Tech. Off. Int. Epiz. 13(4): 11591173.

Tolistiawaty I, Widjaja J, Lobo L T, dan Isnawati, R. 2016. Parasit gastrointestinal pada hewan ternak di tempat pemotongan hewan Kabupaten Sigi, Sulawesi Tengah. BALABA. 12(2): 71-78.

Torr SJ, Mangwiro TNC, Hall DR. 2006. The effects of host physiology on the attraction of tsetse (Diptera: Glossinidae) and Stomoxys (Diptera: Muscidae) to cattle. Bull. Entomol. Res. 96: 71-84.

Vazquez CC, Mendoza IV, Parra MR, Vazquez ZG. 2004. Influence of temperature, humidity and rainfall on field population trend of Stomoxy Calcitrans (Diptera: Muscidae) in a semiarid climate in Mexico. Par. Lat. 59: 99-103.

Widnyana IGNP. 2013. Prevalensi infeksi parasit cacing pada saluran pencernaan sapi bali dan sapi rambon di Desa Woso Kecamatan Bungku Barat Kabupaten Morowali. J. Agro. Pet. 10(2): 1-8. 